Eighteenth-Century Music (C) Cambridge University Press, 2018

doi:10.1017/S1478570617000653

\title{
ARISTOCRATIC WOMEN AMATEURS AND THE POLITICS OF VIRTUOSITY: PLACING THE PARDESSUS DE VIOLE IN ITS SOCIAL AND CULTURAL CONTEXT BOSTON EARLY MUSIC FESTIVAL, 14 JUNE 2017
}

The pardessus de viole is the smallest member of the viola da gamba (viol) family, and was the last to develop and bloom. Its sphere is populated by four instruments: dessus (treble viol), six- and later five-string pardessus, and the quinton; the latter three were cultivated almost exclusively in France. The quinton is a fivestring pardessus in its basic dimensions (length of instrument and strings, frets and tuning) but whose body exhibits violin-family features. Research on these instruments began in earnest only in the late 1970s with the work of Terry Pratt, Adrian Rose and, especially, Robert Green, a pioneer in this area. Accurate information on the pardessus in standard reference works was deficient until recently. The New Grove Dictionary of Musical Instruments (London: Macmillan, 1984) had a single unsigned paragraph for 'pardessus', providing confused five-string tunings and an inaccurate reference to Jean Rousseau's Traité de la viole (1687). Even Marcelle Benoit's Dictionnaire de la musique en France aux XVII et XVIII siècles (Paris: Fayard, 1992) gave scant coverage of the pardessus and its music. Tina Chancey, a scholar-performer increasingly devoted to pardessus repertoire over the last twenty-five years, recently organized a 'mini-conference' on the instrument, supported by the Viola da Gamba Society of America and the Boston Early Music Festival. The first of three events was a symposium with six research presentations.

In the 1970 American viol maker Peter Tourin began a database of antique viols that recorded builders, dimensions, alterations and so forth, calling his product 'Viollist'. Thomas MacCracken (Oakton, Virginia) assumed the project over two decades ago, and recently renamed it 'Database of Historical Viols' (DHV), now an online searchable database on the website of the Viola da Gamba Society of America (vdgsa.org). In his visually rich survey of small French viols, MacCracken pointed out that three-quarters of the over four hundred surviving French instruments belong in the categories of dessus, pardessus or quinton. This impressive number enables us to reach some fascinating conclusions. From their first appearance no later than 1686, six-string pardessus were built approximately twelve per cent smaller than the dessus, instead of the twenty-five per cent that would be acoustically proportional for an instrument tuned a fourth higher. This led to a high string tension and a more brilliant timbre. Five-string pardessus began appearing in the 1730s; Jean Ouvrard may have been the first maker of such instruments, but today half of those that survive (sixty-six instruments!) are by Louis Guersan, who may have never built dessus or basses. MacCracken's informative handout included a list of nearly thirty recordings on twenty antique instruments released between 1954 and 2016, some featuring scholar-performers in attendance at the symposium (Chancey, Simone Eckert and Annalisa Pappano).

A dissertation in progress from the Sorbonne-Paris IV University by Evangelia Kopsalidou (Democritus University of Thrace) is a 'complete catalog of French viola da gamba music (1610-1778)', a welcome and ambitious addition to the field. Kopsalidou spoke on the current state of her research, concentrating on the pardessus portions of her catalogue starting in 1722, and linking the instrument's rise in popularity to the simultaneous decline in repertoire for the bass viol. The pardessus-related materials that Kopsalidou has recorded cover a wide range of source types: manuscript and published compositions, methods, letters and articles in the press. She provided a useful chronological outline of the pardessus, its players and composers, which we anticipate seeing in expanded form as part of her dissertation.

My paper (Stuart Cheney, Texas Christian University), 'Violin or Viol?: An Eighteenth-Century Manuscript Collection for Pardessus de Viole', explored a manuscript of airs copied in the late 1710 and 1720 and labelled by the Bibliothèque nationale de Paris (call number $\mathrm{Vm}^{7} 4867$ ) as a 'Recueil d'airs pour violon seul'. Several features of the manuscript suggest the pardessus de viole as being one of the intended instruments, and among the 178 pieces are over a dozen for bass viol in alto and bass clefs, including a prelude 
by Marin Marais. Yet the source remains almost entirely unknown among viol players and scholars. Bowing indications appear in just three pieces, one of which is for a treble instrument and notated in the $\mathrm{G}^{1}$ clef. In all three cases, the bowings are underhanded - that is, for a viol - suggesting the possibility that all or most of the remaining $G^{1}$ pieces in the manuscript were copied for a dessus or pardessus player. However, idiomatic writing that would help consolidate the case for pardessus, such as chords, thirds or other types of double-stopped harmony, are missing, as are arrangements from the illustrious solo bass viol repertoire.

Treatises for pardessus, like most of its repertoire, were aimed chiefly at amateurs, while most methods for the violin from the same period were intended to guide aspiring professionals. The modern professional pardessus player, then, could benefit from consulting violin treatises and adapting the technical exercises found there. In her presentation, Simone Eckert (Hamburg Ratsmusik and Hamburger Conservatorium) examined methods associated directly with the pardessus, such as Michel Corrette's Méthode pour apprendre facilement à jouer du Par-dessus de Viole à 5 et à 6 Cordes (Paris: author, 1748) and the Méthode nouvelle et facile pour apprendre a jouer du par-desssus de viole (Lyon: Aimé Delaroche, 1766) by Posuel de Verneaux (C. R. Brijon), before bringing contemporaneous violin treatises into the discussion. Some French methods for violin (Pierre Dupont, Principes de violon par demandes et par réponce (Paris: author, 1718)) or flute (Toussaint Bordet, Méthode raisonnée (Paris: author, 1755)) mention the pardessus, often with only basic information on tuning and bowing. Applying contemporaneous violin pedagogy to the pardessus, Eckert has discovered several exercises that also benefit pardessus study. Giuseppe Tartini's pedagogical writings, in particular, prove adaptable. Manuscript copies of Tartini's violin method circulated in France, and his treatise on ornamentation appeared in print posthumously in Paris in 1770. Tina Chancey assisted by demonstrating how some of Tartini's advanced bowing exercises, when adjusted for the underhand bow-hold, are excellent for improving pardessus playing techniques.

In 'Gender, Gesture, and Transgression in Late Eighteenth-Century Women's Violin Performance' Hester Bell Jordan (McGill University) refuted the accepted notion that the violin was not much played by women before the twentieth century, pointing out that at least eighty women violinists - both professional and amateur - were born in the eighteenth century. This contradicts many writers of the time who declared the violin to be a masculine instrument. Some accounts that discouraged women from playing violin mention not only the instrument's associations with dance, lower classes and professionalism, but also the physical and visual aspects of playing. Physical gestures required of violinists were thought to be visually unfeminine, especially the faces made by performers. Writers asserted that women were not masculine enough to achieve the best tone and technique, and that quality violin playing failed to benefit from the feminine attributes of passivity and poise. In contrast to these perceptions, a handful of women violinists were active throughout Europe after the middle of the eighteenth century. Lisa Rautenberg played examples from Regina Strinasacchi's Violin Concerto in B flat major. The physical gestures required by this work illustrate ambiguous eighteenth-century attitudes toward what constituted appropriately feminine physical movements. For example, 'vulgar' leaps in pitch require string-crossings, which draw attention to awkward, unfeminine motions. Bell Jordan raised the question of whether Strinasacchi sought on some level to highlight the provocative visual aspects of her virtuosity.

Beverly Jerold (Princeton, New Jersey) pointed out in 'The Myth of the Inferior Amateur' that while the modern sense of the term 'amateur' implies a lower level of talent or achievement, during the eighteenth and nineteenth centuries class associations dictated the meaning of the term. Many musical amateurs in eighteenth-century Europe were as proficient as professionals, but their relatively high social status (by comparison with professional musicians) precluded the need for remuneration. Amateurs were valued for their taste, wide knowledge of the fine arts and ability to write about music. Some amateurs may have avoided matching the talents of professionals because an ability to play too well implied over-seriousness, an imbalance that prevented one's being a well-rounded person. Among the most famous amateurs of the period was Joseph Bologne, Chevalier de Saint-Georges, who played violin and led the Concert des Amateurs, one of Europe's finest orchestras. Except for singers, nearly all women who performed in public were amateurs. Writers such as Titon du Tillet in Le Parnasse François (Paris: Coignard Fils, 1732) list women among the 
great musical amateurs of their day. Some name prominent women amateur pardessus players: Mademoiselle de Bernay was depicted by the painter Carmontelle 'jouant à la pardessus de viole' (what we would call a quinton), while Stéphanie-Felicité du Crest, Contesse de Genlis, played both harp and pardessus.

The symposium was followed by a concert on 15 June that featured five pardessus players performing eight works. The next day a series of lecture-demonstrations took place that included further performances, along with explanations of all four pardessus-type instruments. Attendance was very healthy on all three days, demonstrating that the pardessus could compete well among the tremendous wealth of the Boston Early Music Festival as a whole.

STUART CHENEY

s.cheney@tcu.edu

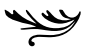

Eighteenth-Century Music $\odot$ Cambridge University Press, 2018

doi:10.1017/S1478570617000665

OPERA'S CANONIC ENTANGLEMENTS

INTERNATIONAL STUDY CENTRE AT ČESKÝ KRUMLOV, 20-23 JUNE 2017

This conference was organized as part of the research project Opera and the Musical Canon, 1750-1815, based at the Fountain School of Performing Arts, Dalhousie University. Conveners Estelle Joubert and Austin Glatthorn invited researchers from Canada, the United States, Great Britain, Germany and Austria to the beautiful Bohemian town of Český Krumlov, a UNESCO World Heritage Site, to discuss aesthetics, the work concept and canon formation in central European opera c180o. Each presenter gave an hour-long paper, followed by extensive questions and discussions.

The conference opened with a keynote address delivered by Martin Nedbal (University of Kansas). He focused on the ideological approaches that lay behind Italian-, German- and Czech-language productions of Don Giovanni at Prague's Estates Theatre over the course of a century, 1787-1887. Between its world premiere by the company of Domenico Guardasoni and the festively celebrated centenary of its continuous presence on the stage, Mozart's opera served as a means of promoting increasingly nationalistic attitudes on the part of the two ethnic groups living in Bohemia. Archival sources reveal how nineteenth-century Czech-language adaptations opposed the dominant German culture by adhering to the original Italian production, which was associated with the city's prestigious status as a centre of Mozart opera performance, rather than following the singspiel tradition. After this presentation, the first day concluded with a friendly dinner in one of the town's restaurants specializing in delicious regional cuisine.

On the second day participants gathered for the morning session, 'Canonic Endeavours in Warsaw and Berlin'. My own paper (Anna Parkitna, Stony Brook University) was on the role of Polish adaptations of Italian operas, initiated by Wojciech Bogusławski (1779) and driven by his rivalry with foreign operatic companies, in the creation of a standard repertory at Warsaw's public theatre. I argued that while emerging eighteenth-century operatic practices in the vernacular may have reflected national aspirations stirred by the Enlightenment, this cannot be separated from the trend for retaining highly popular operas in the repertory for longer and repeating them more often. Thereafter Eric Schneeman (University of Texas at San Antonio) investigated operatic canon formation in Berlin during the first half of the nineteenth century within the context of the concurrent construction of the Königliches Museum, which was an element of the Prussian authorities' plan to protect historical objects of national significance. In the aftermath of the Napoleonic Wars, German critics emphasized the need to preserve operas by Gluck and Mozart in the Berlin opera house and 